\title{
PENGARUH RISIKO KREDIT DAN KECUKUPAN MODAL TERHADAP PROFITABILITAS
}

\author{
Puspa Widyadari Munggar \\ Universitas Singaperbangsa Karawang \\ $1710631030011 @$ student.unsika.ac.id ${ }^{1 *}$, \\ Gusganda Suria Maria \\ Universitas Singaperbangsa Karawang
}

\begin{abstract}
The purpose of this study was to determine the effect of credit risk and capital adequacy on profitability in state-owned banking companies. The research method in this study used quantitative methods with verification descriptive analysis, while purposive sampling was a sampling technique used. The data used is secondary data, namely the financial statements of state-owned banking companies for the 2015-2019 period listed on the Indonesia Stock Exchange. The sample used in this study were 4 stateowned banking companies. The results showed that credit risk had a negative and significant effect on profitability, with a negative regression coefficient of -0.531 and a significance value of $0.002<0.05$. While capital adequacy has a positive and significant effect on profitability, with a positive regression coefficient of 0.317 and a significance value of $0.001<0.05$. Credit Risk and Capital Adequacy have a significant effect on Profitability with an R Square value of $71.1 \%$.
\end{abstract}

Keywords : Credit Risk, Capital Adequacy, Profitability

\section{PENDAHULUAN}

Pada saat era modern ini, dalam meningkatkan perekonomian suatu negara peran bank sangatlah penting. Berbagai aktivitas keuangan dari hampir seluruh sektor yang terkait selalu memerlukan layanan perbankan. Maka dari itu, seluruh perekonomian akan mendapatkan keuntungan dari adanya perbankan. Gagasan dasar dari kegiatan perbankan ialah rasa percaya masyarakat. Rasa percaya masyarakat terhadap dana tabungan bank begitu dipengaruhi dengan informasi tentang kinerja dan kualitas bank melalui penilaian tingkat kesehatan bank. Apabila bank mengalami peningkatan kesehatan maka diharapkan kinerjanya pun akan meningkat sehingga menunjang reputasinya.

Dalam mengukur kinerja suatu bank, salah satu hal yang bisa dipergunakan ialah dengan laporan keuangan. Dimana dalam laporan keuangan kita dapat melihatnya dari profitabilitas bank tersebut. Sedangkan dalam menjalankan aktivitas usaha, tujuan utama bank sendiri yakni memaksimalkan tingkat profitabilitas. Yang dimaksud dengan profitabilitas ialah kemampuan suatu bank mengenai cara memperoleh / menghasilkan keuntungan secara efektif. Biasanya, keuntungan yang didapatkan perusahaan datang dari penjualan dan pendapatan investasi. Kuncinya ialah sebuah profitabilitas menunjukkan efisiensi perusahaan (Kasmir, 2002)

\section{KAJIAN PUSTAKA DAN PENGEMBANGAN HIPOTESIS}

Pengaruh Risiko Kredit Terhadap Profitabilitas

Terdapat beberapa faktor yang mempengaruhi profitabilitas, diantaranya risiko kredit dan kecukupan modal. Pada penelitian ini dalam mengukur risiko kredit alat yang dapat dipergunakan ialah Non Performing Loan (NPL). 
Menurut (Dendawijaya, 2009) adanya kredit macet memberikan dampak yang tidak lumrah, salah satunya ialah dalam memperoleh pendapatan dari pinjaman suatu perusahaan mengalami kehilangan kesempatan yang kemudian dapat menurunkan profitabilitas yang berdampak negatif terhadap profitabilitas bank. Beberapa penelitian yang sudah dilakukan sebelumnya tentang pengaruh risiko kredit terhadap profitabilitas mendapatkan hasil yang beragam. Menurut (Putri, 2013) pada penelitiannya menyatakan profitabilitas dipengaruhi secara negatif dengan NPL, dan ini memiliki kesamaan dengan penelitian (Halimah, 2016) risiko kredit berpengaruuh negatif terhadap profitbilitas. Hasil penelitian tersebut didukung oleh Ni Luh Putu Agustin dkk (2017) menurut penelitiannya risiko kredit mempunyai pengaruh yang negatif signifikan terhadap profitabilitas. Lain halnya menurut (Sukma, 2013) mengemukakan risiko kredit berpengaruh positif terhadap profitabilitas.

$\mathrm{H}_{1}$ : Pengaruh Risiko Kredit Terhadap Profitabilitas

\section{Pengaruh Kecukupan Modal Terhadap Profitabilitas}

Rasio kecukupan modal dalam penelitian ini diproyeksikan dengan rasio Capital Adequacy Ratio (CAR). Menurut (Dendawijaya, 2009) CAR ialah suatu rasio dimana digunakan untuk menunjukan seberapa besar total semua aktiva bank yang berisiko ikut dibiayai dari modal bank sendiri selain mendapatkan dana dari sumber yang selain bank (misalnya dana masyarakat, pinjaman, dan lain-lain). Nilai CAR yang diperoleh bank mengalami peningkatan maka kinerja bank tersebut semakin baik, sehingga laba bank akan mengalami kenaikan.

Terdapat sejumlah penelitian terdahulu mengenai pengaruh CAR terhadap profitabilitas yang memiliki hasil yang beragam atau berbedabeda. Menurut (Putri, 2013) Capital Adequacy Ratio berpengaruh positif dan signifikan terhadap profitabilitas. Sejalan dengan hasil penelitian (Agustini et al., 2017) kecukupan modal berpengaruh positif signifikan terhadap profitabilitas. Sedangkan menurut (Sukma, 2013) menyatakan bahwa profitabilitas tidak dipengaruhi oleh kecukupan modal. Hal ini berbeda dengan penelitian (Halimah, 2016) variabel kecukupan modal (CAR) mempunyai penagruh yang negatif signifikan terhadap profitabilitas (ROA). Berdasarkan latar belakang dan hasil penelitian terdahulu diatas mengenai faktor-faktor yang mempengaruhi profitabilitas, maka dari itu penulis tertarik untuk menjalankan penelitian mengenai "Pengaruh Risiko Kredit Dan Kecukupan Modal Terhadap Profitabilitas Pada Perbankan Bumn Yang Terdaftar Di BEI Periode 2015-2019",

$\mathrm{H}_{2}$ : Pengaruh Kecukupan Modal Terhadap Profitabilitas

\section{METODOLOGI PENELITIAN Populasi dan Sampel}

Penelitian ini dilakukan di perusahaan perbankan yang terdaftar di BEI pada tahun 2015-2019 dengan populasi sebanyak 44 perusahaan. Dari banyaknya populasi tersebut maka sampel yang dipergunakan ialah 4 perusahaan dengan menggunakan teknik nonprobabillity sampling dengan pendekatan purposive sampling. Sumber data yang digunakan yaitu data sekunder yang didapat melalui website resmi BEI (www.idx.co.id) yaitu laporan keuangan tahunan perusahaan perbankan periode 2015-2019 serta pengumpulan data menggunakan metode dokumentasi.

Tabel 1 Perusahaan Perbankan yang Menjadi Sampel Penelitian

\begin{tabular}{c|c|c}
\hline No & Kode & Nama Perusahaan \\
\hline \hline 1 & BBNI & PT Bank Negara Indonesia Tbk \\
2 & BBRI & PT Bank Rakyat Indonesia Tbk \\
3 & BBTN & PT Bank Tabungan Negara Tbk \\
\hline
\end{tabular}




\begin{tabular}{c|c|c}
\hline 4 & BMRI & PT Bank Mandiri \\
\hline Source: data yang diolah
\end{tabular}

\section{Metode Analisis Data}

Menurut (Sugiyono, 2017) metode penelitian ialah suatu cara yang ilmiah demi memperoleh data dengan maksud dan tujuan serta manfaat khusus. Pada penelitian ini metode yang dipergunakan ialah metode deskriptif kuantitatif serta analisisnya menggunakan statistik.

Analisis linear berganda dengan bantuan software SPSS 16 merupakan uji hipotesis yang dipergunakan pada penelitian ini. Untuk penelitian ini persamaan regresinya ialah :

$$
\mathrm{Y}=\alpha+\beta 1 \mathrm{X} 1+\beta 2 \mathrm{X} 2+\varepsilon
$$

$\alpha=$ Konstanta

$\beta 1=$ Koefisien regresi berganda

$\beta 2=$ Koefisien regresi berganda

$\mathrm{X} 1=$ Non Performing Loan (NPL)

$\mathrm{X} 2=$ Capital Adequacy Ratio (CAR)

$\mathcal{E}=$ Tingkat kesalahan

\section{HASIL DAN PEMBAHASAN}

Metode deskriptif ialah metode yang dipergunakan demi menganalisis data dengan mendeskripsikan data atau menggambarkan data yang sudah dikumpulkan, dan tidak dimaksudkan untuk membuat kesimpulan atau generalisasi secara umum. Berikut hasil uji analisis deskriptif

Dimana :

$\mathrm{Y}=$ Profitabilitas

Tabel 2 Hasil Analisis Deskripstif

\begin{tabular}{l|c|c|c|c|c}
\hline & N & Minimum & Maximum & Mean & Std. Deviation \\
\hline NPL & 20 & 30 & 4,78 & 2,6720 & $\mathbf{9 4 1 4 6}$ \\
CAR & 20 & 16,97 & 22,6 & 20,0740 & $\mathbf{1 , 7 9 1 0 3}$ \\
ROA & 20 & 13 & 4,19 & 2,6335 & $\mathbf{9 9 2 6 9}$ \\
Valid N (listwise) & 20 & & & & \\
\hline \hline
\end{tabular}

Source: data yang diolah

Hasil analisis deskriptif menunjukkan bahwa pada penelitian ini sampel yang dipergunakan yaitu 20 data. Diketahui bahwa variabel dependen profitabilitas (ROA) memperlihatkan nilai mean (rata - rata) yaitu 2,6335, sedangkan nilai standar deviasi yaitu 99269, dengan 4,19\% nilai maksimum dan $13 \%$ nilai minimum.

Variabel independen yaitu NPL mempunyai nilai mean sebesar 2,6720 dengan nilai standar deviasi sebesar 94146, nilai maksimum 4,78\% dan minimum $30 \%$.

Dan variabel independen yang terakhir yaitu CAR menunjukan mean 20,0740 dengan nilai deviasi sebesar 1,79103, nilai maksimum $22,96 \%$ dan nilai minimum $16,97 \%$.

Untuk mengetahui distribusi data dalam variabel yang nantinya akan digunakan pada penelitian, apakah data tersebut memiliki distribusi yang normal atau tidak dapat menggunakan uji normalitas. Dalam penelitian ini uji normalitas memakai Kolmogorov Smirnov. Dimana memiliki ketentuan apabila nilai Asymp. Sig. (2 tailed) $>0,05$ berarti normalnya data yang terdistribusi. Sedangkan apabila nilai Asymp. Sig. (2 tailed) $<0,05$ ini berarti sebaliknya atau data yang terdistribusi tidak normal. Hasil pengujian normalitas didapatkan bahwa secara keseluruhan data variabel independen dan dependen dalam penelitian ini terdistribusi secara normal dengan nilai residual yaitu 0,971 , sebab nilai signifikasi $0,971>0,05$. Oleh karena itu model regresi layak dipergunakan dalam penelitian. 
Tabel 3 Hasil Uji Normalitas

\begin{tabular}{l|c|c}
\hline & & Unstandarized Residual \\
\hline \hline $\mathrm{N}$ & & 20 \\
Asymp. Sig. (2-tailed) &, 971 \\
\hline
\end{tabular}

Source: data yang diolah

Uji multikolinearitas mempunyai tujuan untuk dilakukan uji apakah ditemukan atau terdapat korelasi antar variabel independen pada model regesi. Apabila nilai $\mathrm{t}>0,10$ dan nilai VIF $<10$ hal ini berarti suatu model regresi bisa dinyatakan bebas dari multikolinearitas. Hasil uji multikolinearitas pada variabel penelitian ini diperoleh t untuk variabel NPL adalah 0,949> 0,10 dan nilai VIF $1,054<10$. Sehingga dinyatakan tidak terjadi multikolinearitas pada variabel NPL. Variabel CAR memiliki nilai $\mathrm{t}$ yaitu $0,949>0,10$ dan nilai VIF $1,054<10$. Sehingga dinyatakan bebas multikolinearitas dalam variabel CAR.

Hasil persamaan analisis regresi linear berganda dalam penelitian ini yakni :

Profitabilitas $(Y)=-2,305+-0,531$ NPL $+0,317$ CAR + e

$\alpha=-2,305$. Nilai $\alpha$ menunjukkan arah negatif. Ini menunjukkan apabila tak terdapat variabel independen yang berubah yaitu risiko kredit dan kecukupan modal atau memiliki nilai 0 , berarti profitabilitas sebagai variabel dependen akan tetap bernilai sebesar $-2,305 \%$. Variabel risiko kredit (NPL) bernilai koefisien regresi negatif, yang berarti bahwa tak adanya hubungan yang searah antara variabel NPL dengan profitabilitas. Koefisien variabel $\mathrm{X} 1$ yaitu $-0,531$, yang artinya bahwa setiap tingkat NPL yang mengalami kenaikan atau pertambahan sebesar satu-satuan dapat berakibat pada penurunan profitabilitas senilai $-0,531 \%$. Variabel kecukupan modal (CAR) mempunyai koefisien regresi yang memiliki nilai positif, ini memperlihatkan terdapat hubungan yang searah antara variabel CAR dengan profitabilitas. Koefisien variabel $\mathrm{X}_{2}$ yaitu 0,317 , yang artinya bahwa setiap tingkat pertumbuhan penjualan satu-satuan menagalami kenaikan atau pertambahan dapat berakibat pada peningkatan profitabilitas sebesar $0,317 \%$.

\section{Uji F}

Berdasarkan pengujian uji $\mathrm{F}$ memperlihatkan hasil yaitu 20.910 yang signifikan pada 0,000. Jadi Fhitung > Ftabel $(20,910>3,49)$ dan nilai (sig $0,000<0,05)$. Maka dapat diartikan bahwa model yang digunakan dalam penelitian ini adalah layak.

\section{Koefisien Determinasi}

Demi untuk mengetahui kemampuan variabel independen (NPL dan CAR) dalam menjelaskan variabel dependen (ROA) dapat menggunakan koefisien determinasi. Nilai koefisien determinasi ialah antara 0 dan 1. Dari hasil penelitian diperoleh nilai koefisien determinasi atau R2 sebesar 0,711 atau 71,1\%. Maka dapat diartikan bahwa risiko kredit dan kecukupan modal sebagai variabel yang diteliti berpengaruh senilai $71,1 \%$ terhadap profitabilitas. Sedangkan $28,9 \%$ atau sisanya dapat dipengaruhi oleh variabel lain yang tak ikut diteliti pada penelitian ini

\section{Uji t}

Pengujian hipotesis secara parsial yakni uji $\mathrm{t}$ yang memiliki tujuan untuk membandingkan antara hasil nilai $t$ dari perhitungan statistik dengan nilai t tabel dalam persamaan regresi demi mencari pengaruh antara variabel independen terhadap variabel dependen.

\section{Pengaruh Risiko Kredit Terhadap Profitabilitas}

Dari hasil uji yang dilakukan pada hipotesis pertama yakni risiko kredit (NPL) 
yang memiliki nilai thitung $(-3.765)<$ ttabel $(2,08596)$ dan sig. $(0,002)<\alpha(0,05)$ maka H0 diterima dan $\mathrm{H} 1$ ditolak. Hal ini dapat diartikan bahwa profitabilitas dipengaruhi secara negatif oleh NPL perusahaan perbankan BUMN yang terdaftar di BEI. Dengan demikian hipotesis pertama (H1) ditolak.

Hasil analisis data membuktikan bahwa tidak adanya pengaruh NPL terhadap ROA. NPL yang berpengaruh negatif dalam penelitian ini dapat berarti bahwa kredit bermasalah pada pengelolaan kredit bank yang diproyeksikan dengan rasio NPL yang semakin tinggi tersebut dapat berpengaruh pada tingkat pendapatan bank yang digambarkan dengan ROA yang mengalami penurunan. Hal ini sejalan dengan penelitian (Putri, 2013) dan (Halimah, 2016) yang mengemukakan terdapat pengaruh yang negatif NPL terhadap profitabilitas.

\section{Pengaruh Kecukupan Modal Terhadap Profitabilitas}

Pada penelitian ini Hipotesis kedua ialah kecukupan modal (CAR) yang memiliki nilai thitung (4.269) > ttabel $(2,08596)$ dan sig. $(0,001)<\alpha(0,05)$ maka H0 ditolak dan H2 diterima. Hal ini dapat diartikan bahwa profitabilitas diperangaruhi secara positif oleh CAR pada perusahaan perbankan BUMN yang terdaftar di BEI. Dengan demikian hipotesis kedua (H2) diterima.

Adanya pengaruh CAR terhadap ROA. Pengaruh positif CAR yang bernilai tinggi ini berarti bank memiliki kecukupan modal bernilai tinggi, Tingginya permodalan yang dimiliki bank dapat membuat bank dengan leluasa menggunakan dananya demi investasi yang dapat memberikan untung kepada bank, yang dapat membuat kepercayaan nasabah meninggi karena bank cenderung mendapatkan keuntungan yang tinggi. Selain itu, semakin tinggi permodalan bank, semakin tinggi keamanan ekspansi bisnis bank. Adanya ekspansi bisnis pada akhirnya dapat membuat kinerja keuangan bank terpengaruhi. Dalam penelitian ini memiliki hasil yang sama dengan penelitian (Putri, 2013) dan (Agustini et al., 2017) menunjukkan CAR memiliki pengaruh yang positif dan signifikan terhadap ROA

\section{KESIMPULAN}

Berdasarkan hasil peneletian, maka dapat disimpulkan bahwa risiko kredit yang diproyeksikan oleh rasio Non Performing Loan (NPL) memiliki pengaruh negatif dan signifikan terhadap profitabilitas, sedangkan kecukupan modal yang diproyeksikan dengan rasio Capital Adequacy Ratio (CAR) memiliki pengaruh positif dan signifikan terhadap profitabilitas serta adanya pengaruh NPL dan CAR secara simultan terhadap profitabilitas pada perusahaan perbankan BUMN yang terdaftar di Bursa Efek Indonesia (BEI) pada tahun 2015-2019.

Saran untuk perusahaan diharapkan dapat menjaga rasio kecukupan modal yang diukur dengan rasio kecukupan modal. Karena pengelolaan modal yang baik, penggunaan modal sendiri sebaik-baiknya dapat membuat tingkat keuntungan perusahaan yang tercermin dari ROA dapat mengalami peningkatan. Bagi peneliti yang selanjutnya diharapkan akan ditambahkan variabel independen lain yang dapat mempengaruhi profitabilitas perusahaan bank, dan jumlah sampel yang akan digunakan untuk penelitian akan bertambah, yang akan menambah periode pengamatan dan mengubah metode penentuan sampel.

\section{DAFTAR PUSTAKA}

Agustini, N. L. P., Wiagustini, N. L. P., \& Purbawangsa, I. B. A. (2017). PENGARUH KECUKUPAN MODAL DAN RISIKO KREDIT PROFITABILITAS: TERHADAP SEBAGAI PEMEDIASI Pada Bank Perkreditan Rakyat di Kabupaten Badung. E-Jurnal Ekonomi Dan Bisnis Universitas Udayana, $\quad 6, \quad 2161-2192$. https://ojs.unud.ac.id/index.php/EEB/article /view/29485 
Puspa Widyadari Munggar \& Gusganda Suria Marial Pengaruh Risiko Kredit Dan Kecukupan Modal

Terhadap Profitabilitas

Dendawijaya, L. (2009). Manajemen Perbankan. Ghalia Indonesia.

Dirvi, D. S. A., Eksandy, A., \& Mulyadi, M. (2020). Pengaruh Growth Opportunity, Nwc, Cash Conversion Cycle, Ios Dan Leverage Terhadap Cash Holding. Jemasi: Jurnal Ekonomi Manajemen Dan Akuntansi, 16(1), 44-58

Halimah, D. N. (2016). Analisis Pengaruh Risiko Kredit Dan Kecukupan Modal Terhadap Profitabilitas Di Bank Umum Syariah Nasional (BUSN) Devisa Dan Non Devisa Periode 2010-2014.

Kasmir. (2002). Dasar-dasar Perbankan. PT. Raja Grafindo Prsada.
Putri, F. S. (2013). PENGARUH RISIKO KREDIT DAN TINGKAT KECUKUPAN MODAL TERHADAP TINGKAT PROFITABILITAS PADA PERUSAHAAN PERBANKAN YANG TERDAFTAR DI BURSA EFEK INDONESIA. In Jurnal Akuntansi (Vol. 1, Issue 1). www.idx.co.id.

Sugiyono. (2017). Metode penelitian kuantitatif,kualitatif dan R\&D. Alfabeta.

Sukma, Y. L. (2013). Pengaruh Dana Pihak Ketiga, Kecukupan Modal Dan Risiko Kredit Terhadap Profitabilitas (Perusahaan Perbankan yang Terdaftar di BEI). In Jurnal Akuntansi (Vol. 1, Issue 2). www.idx.co.id. 